\title{
THE CITY IN ITS STRUGGLE AGAINST URBAN SHOCKS OR THE ROAD TOWARDS THE RESILIENT CITY
}

\author{
Liviu Bogdan VLAD * \\ Academia de Studii Ecomonice, e-mail: liviubogdanvlad@yahoo.com \\ Eduard CEPTUREANU \\ Academia de Studii Ecomonice, e-mail: eduard_ceptureanu@yahoo.com \\ Sebastian Ceptureanu \\ Academia de Studii Ecomonice, e-mail: ceptureanu@yahoo.com
}

\begin{abstract}
Citation: Vlad, L. B., Ceptureanu, E., Ceptureanu, S. (2019). The City in Its Struggle Against Urban Shocks or the Road Towards the Resilient City. Revista Română de Geografie Politică, 21(1), 29-34. https://doi.org/10.30892/rrgp.211104-330
\end{abstract}

\begin{abstract}
The challenges Europe faces nowadays greatly affect cities as well. Globalization, climate changes, migration, demographic decline and energetic security are true shocks for urban centers. These shocks offer cities some of the most significant reasons to improve resistance and readily implement urban resilience policies. The implementation of said policies is necessary also due to the fact that cities nowadays are often blamed for the high level of greenhouse gas emissions that are a shock for the environment and for the inhabitants, who are forced to face them every day.
\end{abstract}

Key words: city, urban shocks, durable development, climate changes, urban competition, urban development, durable city, urban resilience

\section{INTRODUCTION}

Human communities in general and urban communities in particular have been facing several risks in the last decades: risks that appear independently from the action/will of people and risks that are the direct and exclusive results of man and the way he chose to act at a certain point (Goudie, 2018; Herman, 2009).

The recent international crisis has had quite a large impact on cities due to its having generated, among other things, the greatest reduction in economic activity, in this sense becoming a real shock for cities that up to that point had been used to a certain rhythm of development. It is difficult to quantify the effects of the crisis upon the urban environment but they are without a doubt significant, especially since in the first half of the $21^{\text {st }}$ century a global process of 
urbanization has begun. Not only have cities grown in number and size - they have turned into complex and multifaceted organisms (Borsekova and Nijkamp, 2018). The challenges raised by the crisis were seconded by the challenges posed by globalization, the latter being viewed as the phenomenon that led to irreversible urban transformations. Along with these problems of economic nature, the city nowadays is permanently under stress and faces shocks daily, the most important of which are environmental and political shocks.

To the extent in which shocks threaten the city at every moment, it is no wonder that one of the most frequently used terms has recently become urban resilience, based firstly on the identification, evaluation and management of risks that threaten modern cities. Urban resilience is directly proportional to the degree in which a city is vulnerable. Although relatively new as a concept, urban resilience has won more and more ground, as it completes durable urban development and represents the ability of cities to withstand the shocks they face. We should mention that, in order to become resilient, cities must first of all adapt to the challenges of urban competition. The road to competitive and resilient cities is not an easy one. It should be based on adopting a series of measures, such as constant investment in the electricity network, the creation of a smart urban transportation network, the improvement and expansion of water supply networks, measures for the prevention and protection against floods etc. Only by adopting these measures can cities today become resilient. For this purpose, by resilient we mean the ability of cities to recover from shocks or adapt to them, gaining benefits from their positive effects (Briguglio et al., 2009).

The modern city has surpassed the stage of being a mere settlement with buildings, infrastructure and people. It has become an increasingly complex space that poses many questions regarding environment quality, energy usage, social cohesion, transport infrastructure, public facilities etc. (Borsekova and Nijkamp, 2018). Although modern cities are usually subjected to the same types of risks/shocks, their ability to adapt and respond to challenges varies immensely. This is due to some crucial factors, such as: government, institutions, cultural habits, technology, wealth, urban planning (Borsekova et al., 2018). Therefore, a well-developed city with a government oriented towards progress will recover much easier than a less developed city.

This paper is aimed at studying the way in which shocks affect the normal activity of the city and at identifying the main measures that should be taken in order to reduce the negative consequences of stress and shocks on the natural development of cities by as much as possible. By shocks we understand the totality of challenges that cities nowadays are confronted with, from climate changes to economic changes, from the demographic to the energetic situation and from political crises to the acute crisis of space. However, we must not overlook financial shocks - the disturbances that arise directly from the financial sector and negatively affect the natural development of cities.

At the same time, we will try to sketch the road towards improving the resilience of cities so that they become competitive, real models of economic and social development for the present and especially for the future.

\section{CONTEMPORARY URBAN SHOCKS AND THEIR CONSEQUENCES}

The century we live in is an "urban century", characterized by a continuous growth in the size of cities (Kourtit et al., 2014) which, despite the related challenges and disadvantages, concentrate an increasing number of inhabitants 
and record a substantial increase in their average size (Caragliu et al., 2009). As complex forms of human settlement, cities nowadays face a series of stresses and shocks. The most frequent shocks are environmental in general and climatic in particular. The latter can be defined as unique and relatively recent challenges that threaten life and means of living (Dohertya et al., 2016). Climatic changes have become quite frequent in urban areas in recent years. They are generated by several factors, such as extreme temperatures, the alternation of hot days and very cold days, of draught and excess rain. We must keep in mind that climatic changes are not a singular phenomenon, but usually appear alongside other stresses that manifest themselves on an economical, ecological and political level (Leichenko, 2011).

In order to better understand climatic changes we have to mention that they should be seen as external environmental shocks that are not influenced by human activity (Sanchez et al., 2018) but nevertheless have an important impact on the people by affecting their health and, consequently, their standard of living.

Alongside the environmental shocks caused by climatic changes are those produced by tropical cyclones, monsoons and heat waves that affect urban areas, as well as other increasingly extreme - albeit of different frequency and scale - meteorological phenomena (Lejano, 2019). Such shocks, produced by increasingly frequent and severe meteorological phenomena, lead to the geographical and social isolation of the communities affected by said shocks. They also highlight the difficulties which the communities face when in need of emergency support for their members in order to overcome the shocks.

More often than not, climate changes manifest themselves as global warming, which leads to the degradation of natural ecosystems in the urban environment.

Another category of shocks that the modern city faces are economic shocks, which affect the urban economy on a micro and macro level. Economic shocks can appear on both the product and the service market, as well as on the work market or the financial market. This type of shocks is mainly owed to the rapid and volatile changes of the economic and social environment, while at the same time being a consequence of the economic crisis (Iordan et al., 2015). The main form in which economic shocks manifest themselves in the urban environment is the decrease in the number of economic agents. Economic shocks can include, among others, dismissals, economic recession, unexpected migration influx, aging of the population and all manner of other catastrophes (Borsekovaa et al., 2018).

The economic and demographic evolution of urban centers has highlighted the problems of the urban space, a space that proves increasingly insufficient to insure the optimal combination of living spaces, green spaces and traffic areas. Apart from the lack of space, the continuous growth of the number of inhabitants in urban centers raises another problem - the large number of inhabitants requires an increase in the resources allocated for development and maintenance (Dodman, 2009).

Apart from the problems generated by space, cities today face many other problems that prove to be real challenges (Herman et al., 2016; Lange and McNeil, 2004; Thornton, 2007). One of these problems is urban competition, which has recently become more and more fierce. It is seconded by the permanent resistance cities must put up against a wide variety of shocks, thus insuring they are ready to withstand climate changes on the one hand and urban development and durability on the other. 
Alongside the shocks that happen independently from man's will are those owed exclusively to his activities. This category includes terrorism and cyberattacks, which are increasingly frequent in urban centers (Sanchez et al., 2018).

Globalization, disasters and the population increase have also made their mark on the evolution of contemporary cities. In this respect, the most visible shocks are those owed to the fluctuation of population in the urban environment, which is predictable if we think that there has always been a certain correlation between population and economy in the sense that the human factor is directly responsible for the economic development of the city. The effects that disasters of every kind have on cities are manifold, as they affect the city in its totality: environment, economic development and social development.

Despite the stress and shocks they must face, the ability of cities to develop as centers for habitation, production and cultural development is positive (Borsekovaa et al., 2018).

\section{IDENTIFYING THE MAIN MEASURES OF COMBATING THE EFFECTS OF SHOCKS}

One of the most important challenges of our times is climatic change, whose impact is felt on a global level and affects not only people, but also nature and the economy.

Whatever their nature, shocks have a critical impact on cities, affecting not only the physical urban development, but also the topology, the use of lands, its economy and its society.

The effects of shocks can be overcome only if there is a permanent collaboration in this sense between local and national and/or international authorities.

A measure of good practice in combating the effects of shocks owed to climatic changes is the existence of international funds specifically assigned for the building and promotion of urban resistance in countries with low and medium income (Leichenko, 2011). In parallel, resistance to climate changes must also be promoted, combined with improvements in durability and urban development that should seek to solve all urban problems, regardless if we refer to environmental problems or habitation problems (Leichenko, 2011).

At the same time, we think sustained efforts should be made to significantly reduce global greenhouse gas emissions, thus reducing the severity of climate changes. It is worth mentioning that this will not be possible without a better understanding of the complex system of links between emissions from various sources and their impact on the city, region or country as a whole.

When discussing the shocks caused by extreme meteorological phenomena, the first measure we can take in counteracting their effects is identifying the vulnerable communities and connecting them to communication networks (Lejano, 2019). Another measure that must be taken when such shocks occur is creating special programs oriented towards the needs of vulnerable communities and a permanent interaction with the communities that are in danger, while at the same time overseeing that the resources these communities might need are provided to them.

On the other hand, there is a need for the good use of lands and a more careful managing of water supplies, in combination with the development of a platform for future planning and monitoring the interventions that are needed in order to adapt to climate changes (Dohertya et al., 2016).

The need to fight against shocks on an urban/national/European level is acknowledged by members of the European community who support improving 
resilience in the face of environmental and economic shocks, of natural disasters and of disasters caused by man (The European Commission, 2017).

Economic shocks can only be overcome if scientists and political decision makers identify the means and methods of solving the problems in due time, so that they reduce the consequences of such shocks to a minimum.

\section{CONCLUSIONS}

The first conclusion we can draw from our study is that cities must take all the necessary measures in order to become resilient to as wide a variety of stress and shocks as possible. Only adopting urban policies meant to develop the city and increase its capacity to withstand shocks can lead to competitive cities, capable of facing all the challenges that rise nowadays. An essential role in this regard is played by the local administration that has the task, among others, to focus on urban planning, so that cities get closer and closer to the standard of resilient cities.

The second conclusion is that only an integrated approach of economic, social and environmental problems can be a successful method of obtaining a durable urban development. The structures of the urban systems, regardless if we are talking about lifestyle, infrastructure and built space, requires a gradual transformation as well as supporting/stimulating the transformation in order to obtain durability and to be able to withstand the challenges to come.

The third conclusion is that solving the problems generated by urban shocks goes beyond the borders of the city and, more often than not, requires the involvement of multiple factors. So, if some problems can be solved on a local level, others require the involvement of national and maybe even international organizations. Only a good collaboration between researchers, public actors and political factors can successfully overcome the effects caused by shocks in urban centers.

Another conclusion is that the resilience of the climate must be accompanied by constant efforts of promoting urban development; but this is near impossible without adopting new administration and governing policies for cities, policies that emphasize the demands of the market and, first of all, seek to improve the way in which urban centers meet current needs.

We cannot end without making the point that one of the most serious challenges that future urban policies will have to face will be the cities' recovery potential after an external shock occurs. Adopting a policy in this regard is all the more necessary as threats against cities are in constant growth, be it external meteorological conditions, population dynamics, wars or terrorism.

In an urban context where shocks and stress are owed in good part to the political and economic conditions, resilience appears more and more frequently as a reaction to risk, highlighting the need for a more intense preoccupation on the part of society regarding phenomena that control elements of urban evolution and generate risks.

\section{Acknowledgement}

This work was supported by a grant of Ministry of Research and Innovation CNCS - UEFISCDI, project number PN-III-P4-ID-PCCF-2016-0166, within the PNCDI III project "ReGrowEU - Advancing ground-breaking research in regional growth and development theories, through a resilience approach: towards a convergent, balanced and sustainable European Union”. 


\section{REFERENCES}

Borsekova, K., \& Nijkamp, P. (2018). Smart cities: A challenge to research and policy analysis. Cities nr. 78, 1 - 3.

Borsekova, K., Nijkamp, P., \& Guevara, P. (2018). Urban resilience patterns after an external shock: An exploratory study. International journal of disaster risk reduction, 31, 381-392.

Briguglio, L., Cordina, G., Farrugia, N., Vella, S. (2009). Economic vulnerability and resilience: Concepts and measurements. Oxford development studies, 37(3), $229-247$.

Caragliu, A., Del Bo, C., \& Nijkamp, P. (2011). Smart cities in Europe. Journal of urban technology, 18(2), 65-82.

Dodman, D. (2009). Blaming cities for climate change? An analysis of urban greenhouse gas emissions inventories. Environment and urbanization, 21(1), 185-201.

Doherty, M., Klima, K., \& Hellmann, J. J. (2016). Climate change in the urban environment: Advancing, measuring and achieving resiliency. Environmental Science \& Policy, 66, 310-313.

Goudie, A. S. (2018). Human impact on the natural environment. John Wiley \& Sons.

Herman, G. V. (2009). Omul şi modificările antropice din Câmpia Someşului [The man and anthropogenic changes in Somes Plain]. Editura Universității din Oradea, p. 227 p., ISBN 978-973-759-981-0, Oradea.

Herman, G. V., Baias, Ș., \& Măduța, F. (2016). Aspects Regarding the Brownfields from Oradea City, Bihor County, Romania. Brownfields, friches urbaines et recompositions territoriales La durabilité en question, Olivier DEHOORNE, Huhua CAO, Dorina ILIES, PUAG - Publibook, 25 - 40.

Iordan, M., Chilian, M. N., \& Grigorescu, A. (2015). Regional Resilience in Romania-Between Realism and Aspirations. Procedia Economics and Finance, 22, 627-635.

Kourtit, K., Nijkamp, P., \& Reid, N. (2014). The new urban world: Challenges and policy. Applied Geography, 49, 1-3.

Lange, D., \& McNeil, S. (2004). Clean it and they will come? Defining successful brownfield development. Journal of urban planning and development, 130(2), 101-108.

Leichenko, R. (2011). Climate change and urban resilience. Current opinion in environmental sustainability, 3(3), 164-168.

Lejano, R. P. (2019). Climate change and the relational city. Cities, 85, 25-29.

Sanchez, A., Heijden, J., \& Osmond, P. (2018). The city politics of an urban age: urban resilience conceptualisations and policies. Palgrave Communications, 4(1), 25.

The European Commission (2017). Joint statement by the Council and representatives of the governments of the Members States meeting with the Council, the European Parliament and the Commission, published in the Official Journal of the European Union on 30.06.2017 (2017/C 210/01).

Thornton, G., Franz, M., Edwards, D., Pahlen, G., \& Nathanail, P. (2007). The challenge of sustainability: incentives for brownfield regeneration in Europe. Environmental science \& policy, 10(2), 116-134.

\footnotetext{
Submitted:

March 02, 2019
}

Revised:

May 02, 2019
Accepted and published online: June 26, 2019 